\title{
Cephaloridine Serum Levels in Patients on Maintenance Haemodialysis
}

\author{
J. R. CURTIS,* M.D., M.R.C.P. ; MONICA J. MARSHALL, $†$ B.SC.
}

Qummary: Cephaloridine serum half-life was determined in 11 patients undergoing maintenance haemodialysis. Three of them were anephric. The mean cephaloridine half-life was 10.4 hours. There was an inverse correlation between cephaloridine half-life and the duration of maintenance haemodialysis treatment. Reasons for this are discussed.

The effect of haemodialysis with the Kiil dialyser on cephaloridine half-life was studied in three patients.

Dosage recommendations for patients on maintenance haemodialysis are suggested.

\section{Introduction}

The serum half-life of cephaloridine is prolonged in patients with severe renal failure (Kabins and Cohen, 1965; Kunin and Atuk, 1966). Pryor et al. (1967) reported one patient on maintenance haemodialysis in whom there was a progressive shortening of the cephaloridine serum half-life from 21.5 hours, when the patient had been on maintenance haemodialysis for three months, to 8.2 hours after a further period of 17 months on maintenance haemodialysis.

In the present study the serum half-life of cephaloridine was measured in 11 patients, all of whom were on maintenance haemodialysis. The possible effects of duration on maintenance haemodialysis treatment and of other drugs taken by the patients on the serum half-life of cephaloridine were studied. The effect of haemodialysis was studied in three patients.

Recommendations regarding the dosage schedule suitable for patients on maintenance haemodialysis are given.

\section{Methods}

Observations were made on two women and nine men aged 18 to 40 . All were undergoing maintenance haemodialysis for terminal renal failure with the Kiil dialyser (cuprophane PT 150). Dialysis was carried out for a minimum period of 14 hours twice weekly. The endogenous creatinine clearance in eight patients was less than $5 \mathrm{ml} . / \mathrm{minute}$; the remaining three were anephric. Serum cephaloridine concentrations were assayed by the agar-diffusion technique, Bacillus subtilis N.C.I.B. 8533 being used as the test organism.

The serum half-life was estimated after the intravenous injection of 0.5 or $1 \mathrm{~g}$. of cephaloridine. Blood samples were stored at $-10^{\circ} \mathrm{C}$. until assayed. Serum concentrations were plotted on a semilogarithmic scale against time. An arbitrary serum concentration was chosen on the linear part of the plot, and the time taken for the concentration to fall to half this level was taken as the half-life of cephaloridine.

In three patients the cephaloridine half-life was determined on a day immediately preceding a dialysis. After an interval varying from a few days to one week the cephaloridine halflife was determined during a dialysis. Finally, after a further short interval the cephaloridine half-life was determined on a day immediately following a dialysis. In four patients, after an initial determination of cephaloridine half-life, the half-life was repeated after they had undergone a further period of at least one year's maintenance haemodialysis. In the other four patients the half-life was determined on one occasion only.

* Consultant Nephrologist, Department of Medicine, Charing Cross Hospital Medical School, Fulham Hospital, Londn W.6.

† Head of Bacteriology, Biological Research Department, Glaxo Research Ltd., Greenford, Middlesex.

\section{Results}

The mean cephaloridine half-life for the whole group was 10.4 hours (range $5.25-16.0$; S.D. \pm 3.0 ). There was no significant difference between the three anephric patients and the eight patients with endogenous creatinine clearances of less than $5 \mathrm{ml} . /$ minute. The mean cephaloridine half-life in the anephric patients was 11.43 hours (range 8.75 - 16.0; S.D. \pm $2 \cdot 8$ ), while in those with endogenous creatinine clearances of less than $5 \mathrm{ml} . /$ minute the mean cephaloridine half-life was 9.86 hours (range $5 \cdot 25-14 \cdot 5$; S.D. $\pm 3 \cdot 1$ ).

Relationship of Cephaloridine Half-life to Duration of Maintenance Haemodialysis Treatment.-In four patients the cephaloridine half-life was determined initially when they had been on maintenance haemodialysis for periods varying from 9 to 21 months and then repeated after further maintenance haemodialysis for at least 12 months (Table I). In all

TABLE I.-Cephaloridine Half-life and Duration of Maintenance Haemodialysis

\begin{tabular}{|c|c|c|c|c|}
\hline \multirow[b]{2}{*}{ Case No. } & \multicolumn{2}{|c|}{ Initial } & \multicolumn{2}{|c|}{ Repeat } \\
\hline & $\begin{array}{c}\text { Cephaloridine } \\
\text { Half-life }\end{array}$ & $\begin{array}{c}\text { Duration of } \\
\text { Maintenance } \\
\text { Haemodialysis }\end{array}$ & $\begin{array}{l}\text { Cephaloridine } \\
\text { Half-life }\end{array}$ & $\begin{array}{l}\text { Duration of } \\
\text { Maintenance } \\
\text { Haemodialysis }\end{array}$ \\
\hline $\begin{array}{ll}\ldots & \\
\cdots & \end{array}$ & $\begin{array}{c}12.9 \text { hours } \\
16.0 \% \\
13.6 \% \\
7.7 \%\end{array}$ & $\begin{aligned} 12 & \text { months } \\
9 & \Rightarrow \\
9 & \Rightarrow \\
21 & \Rightarrow\end{aligned}$ & $\begin{array}{c}11.75 \text { hours } \\
11.0 \quad " \\
8.75 \Rightarrow " \\
5.25 \Rightarrow\end{array}$ & $\begin{array}{l}27 \text { months } \\
24 " \Rightarrow \\
21 " \Rightarrow \\
33 "\end{array}$ \\
\hline
\end{tabular}

*Anephric.

four the cephaloridine half-life fell after a further year of maintenance haemodialysis. The cephaloridine half-life for all patients is plotted against the duration on maintenance haemodialysis at the time of determination of the half-life (Fig. 1). There is a significant inverse correlation between the

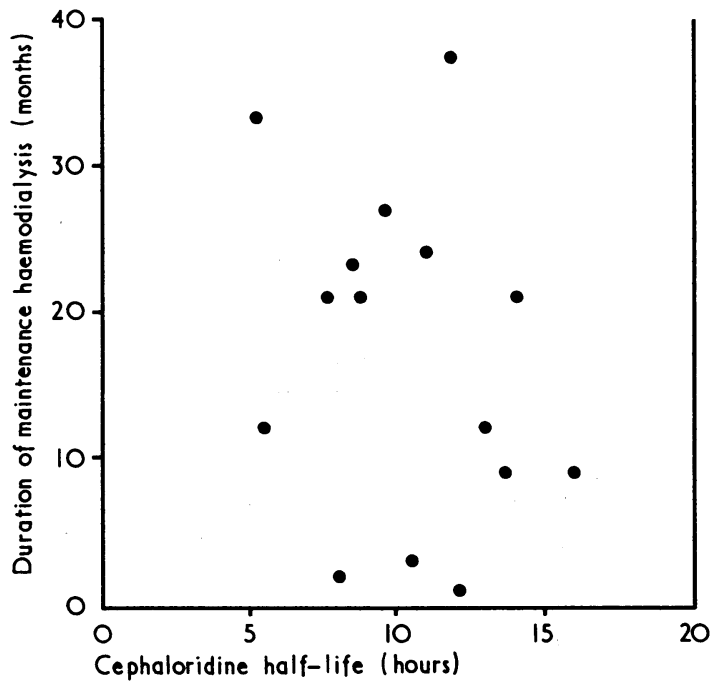

FIG. 1.-Cephaloridine half-life plotted against duration of maintenance haemodialysis treatment.

cephaloridine half-life and the duration of maintenance haemodialysis $(r=0.69 ; \mathrm{P}<0.01)$. There is thus a tendency for the cephaloridine half-life to fall with increasing duration on maintenance haemodialysis. 
Other Factors Possibly Associated with Variation in Cephaloridine Half-life.-All the patients in this study regularly took a medium-acting barbiturate as a hypnotic during overnight dialysis-that is twice weekly. All patients were heparinized twice weekly during haemodialysis.

Previous Treatment with Cephaloridine.-The amount of cephaloridine administered to the patients in this study before the determination of the half-life varied from zero to $84 \mathrm{~g}$. There was no significant correlation between the half-life of cephaloridine and the amount of cephaloridine administered before its determination $(r=0.51 ; 0.2>P>0.1)$.

Warfarin.-The cephaloridine half-life was determined on seven occasions in patients on long-term warfarin therapy and on 11 occasions in patients not receiving warfarin. The mean half-life was 9.42 hours (S.D. \pm 3.37 ) in patients receiving warfarin and 10.99 hours (S.D. \pm 2.73 ) in those not receiving warfarin. There was no significant difference between the means in the two groups $(t=1.08 ; 0.3>P>0.2)$.

Effect of Haemodialysis.-There was no significant difference between the mean cephaloridine half-life determined on pre-dialysis days and that determined on post-dialysis days (Table II). The mean half-life was 10.7 hours on pre-

TABLE II.-Effect of Haemodialysis

\begin{tabular}{|c|c|c|c|}
\hline \multirow{2}{*}{ Case No. } & \multicolumn{3}{|c|}{ Cephaloridine Half-life (Hours) } \\
\hline & Pre-dialysis Day & Post-dialysis Day & During Dialysis \\
\hline $\begin{array}{ll}\because & : \\
\because & \end{array}$ & $\begin{array}{c}14.5 \\
10.0 \\
7.75\end{array}$ & $\begin{array}{c}13.25 \\
9.25 \\
9.2\end{array}$ & $\begin{array}{l}4 \\
2 \cdot 5 \\
4\end{array}$ \\
\hline
\end{tabular}

*Anephric.

dialysis days and 10.5 hours on post-dialysis days. There was, however, a significant fall in cephaloridine half-life during haemodialysis, with a mean level of 3.5 hours $(t=3.554$; $\mathbf{P}<0.05)$. These results strongly suggest that cephaloridine is dialysable.

Serum Levels of Cephaloridine.-The serum levels of cephaloridine achieved after doses of 0.5 and $1 \mathrm{~g}$. intravenously are shown in Fig. 2. Serum levels after 1-g. doses given

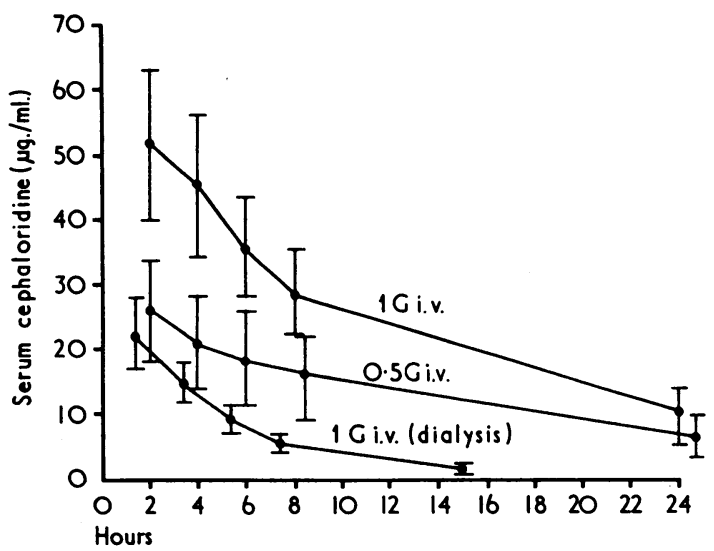

FIG. 2.-Serum cephaloridine levels mean \pm 1 standard deviation) after $1-\mathrm{g}$. and 0.5 -g. doses intravenously and deviation) after $1-\mathrm{g}$. and $0.5-\mathrm{g}$. doses intravenously and
after $1 \mathrm{~g}$. intravenously at the start of haemodialysis.

intravenously at the beginning of haemodialysis are also shown. After $1 \mathrm{~g}$. of cephaloridine intravenously the mean serum level was $51.8 \mu \mathrm{g} . / \mathrm{ml}$. (S.D. \pm 11.6 ) at two hours and reached a mean level of $9.9 \mu \mathrm{g} . / \mathrm{ml}$. (S.D. $\pm 4 \cdot 6$ ) at 24 hours. The mean serum level after $0.5 \mathrm{~g}$. of cephaloridine intravenously was $25.8 \mu \mathrm{g} . / \mathrm{ml}$. (S.D. \pm 7.6 ) at two hours, falling to a mean of $6.2 \mu \mathrm{g} . / \mathrm{ml}$. (S.D. \pm 3.5 ) after 24 hours. The mean two-hour serum level after $1 \mathrm{~g}$. of cephaloridinc intravenously at the beginning of haemodialysis was $22.6 \mu \mathrm{g} . / \mathrm{ml}$. (S.D. \pm 5.4 ) and fell to a mean of $1.5 \mu \mathrm{g} . / \mathrm{ml}$. (S.D. \pm 0.6 ) by the end of a 14-hour dialysis.

\section{Discussion}

The mean cephaloridine half-life in the present group of patients was 10.4 hours and is considerably shorter than that reported by other workers in patients with severe renal failure. Kabins and Cohen (1965) recorded a half-life of 23 hours in patients with creatinine clearances of less than $3 \mathrm{ml} . /$ minute/ 1.73 sq. m. Kunin and Atuk (1966) reported a cephaloridine half-life of 20 hours in patients with creatinine clearances of less than $3 \mathrm{ml} . /$ minute. In the present study the mean cephaloridine half-life in three anephric patients was 11.4 hours (range $8.75-16.0$; S.D. \pm 2.8 ). The explanation for this difference is not clear, but the case reported by Pryor et al. (1967) suggests that for some reason the cephaloridine half-life may fall with increasing duration on maintenance haemodialysis. This suggestion is supported in the present study, in which an inverse correlation between cephaloridine half-life and duration of maintenance haemodialysis treatment is shown. The reasons for this correlation remain unknown, but presumably extrarenal mechanisms of cephaloridine degradation-for example in the liver-become increasingly important with increasing duration of maintenance haemodialysis.

The possible role of other drugs taken by these patients on the cephaloridine half-life was also investigated because of the possibility of enzyme induction in the liver by another drug, with consequent shortening of the cephaloridine halflife. Barbiturates are known to have enzyme-inducing properties and were taken regularly though intermittently by all the patients in the present study. It is possible, therefore, that barbiturates were responsible for the shortening in cephaloridine half-life with increasing duration of maintenance haemodialysis observed in these patients. Another possible factor is heparin, since all patients are heparinized during haemodialysis. Some of these patients were also on long-term continuous warfarin therapy, but no significant difference in cephaloridine half-life was found between those on warfarin treatment and those not receiving this drug.

There was no correlation between the amount of cephaloridine received before the determination of the half-life and the cephaloridine half-life itself.

The shortening of the cephaloridine half-life during haemodialysis which was reported by Kunin and Atuk (1966) is confirmed in the present study.

Presumably cephaloridine is dialysed out during haemodialysis, though no attempt has been made to detect cephaloridine in the effluent dialysis fluid.

Despite the variation in cephaloridine half-life reported in this study it has been possible to utilize a uniform dosage schedule in patients on maintenance haemodialysis. This dosage schedule was established from a consideration of the serum levels achieved after doses of 0.5 and $1 \mathrm{~g}$. intravenously (Fig. 2). Naumann (1967) suggested that the boundary between "sensitive" and "resistant" organisms be defined as a minimum inhibitory concentration of $25 \mu \mathrm{g}$. $/ \mathrm{ml}$. for cephaloridine. Most Gram-positive cocci have minimum inhibitory concentrations well below $25 \mu \mathrm{g} . / \mathrm{ml}$., and a dosage schedule in patients on maintenance haemodialysis infected by those organisms of $1 \mathrm{~g}$. intravenously per day when not dialysed and $1 \mathrm{~g}$. intravenously every six hours during haemodialysis is suggested.

For infections due to Gram-negative bacilli or enterococci, a dosage schedule of $1 \mathrm{~g}$. intravenously every 12 hours when not dialysed and $1 \mathrm{~g}$. intravenously every four hours during haemodialysis is suggested. Haemodialysis in this study was carried out with the Kiil dialyser, and more frequent doses during dialysis would be necessary if a more efficient dialyser such as the twin-coil type were used.

The cephaloridine in doses of 0.5 to $1 \mathrm{~g}$. was given intravenously in $20 \mathrm{ml}$. of $0.9 \%$ saline over five minutes without any side-effects. It is a particular advantage to be able to give 
a drug intravenously in a small volume to patients on maintenance haemodialysis, for not only are these patients heparinized during haemodialysis but many are also on long-term continuous warfarin therapy, and there is a very real danger of large haematomata forming after intramuscular injections.

Cephaloridine has been used widely in the maintenance haemodialysis unit at Fulham Hospital and side-effects have been limited to the occurrence of a sensitivity rash in one patient. The possibility of nephrotoxic side-effects is not important in these patients.
We are grateful to Mr. A. J. Pinegar, Glaxo Research Ltd., who carried out the microbiological assays, and to Sister J. M. Storey and the nursing staff of the maintenance haemodialysis unit, Fulham Hospital, who assisted in the collection of blood samples.

$$
\text { REFERENCES }
$$

Kabins, S. A., and Cohen, S. (1965). Antimicrobial Agents and Chemotherapy, 5, 922

Kunin, C. M., and Atuk, N. (1966). New England fournal of Medicine, 274,654 .

Naumann, P. (1967). Postgraduate Medical fournal, 43, August Suppl.,

pryor, J. S., Joekes, A. M., and Foord, R. D. (1967). Postgraduate Medical fournal, 43, August Suppl., p.82.

\title{
Burning-feet Syndrome. Case Due to Malabsorption and Responding to Riboflavine
}

\author{
C. S. LAI, ${ }^{*}$ M.B., M.R.C.P., M.R.C.P.ED.; G. A. RANSOME, † P.J.G., C.B.E., A.M., M.D., F.R.C.P.
}

\begin{abstract}
ummary: A woman with the burning-feet syndrome $\checkmark$ was found on investigation to have malabsorption. The syndrome responded rapidly to intramuscular injections of $6 \mathrm{mg}$. of riboflavine daily. It is suggested that deficiency of this substance, due to malabsorption and aggravated by a defective diet and repeated pregnancies, was responsible for the syndrome in this case.
\end{abstract}

\section{Introduction}

Burning pain in the feet was known to occur as a result of nutritional deficiency in tropical countries (Stannus, 1912; Landor and Pallister, 1935) and was a common disorder during the Spanish Civil War (Peraita, 1946) and in Japanese prisoner-of-war camps in the Far East during the second world war (Cruickshank, 1946; Smith and Woodruff, 1951). Most patients in these reports had coexisting clinical features suggestive of riboflavine and other vitamin deficiency, and they improved after being treated with yeast, rice polishings, or Marmite. The aetiology of the burning-feet syndrome, however, remained obscure, the deficient factor having been variously attributed to riboflavine (Landor and Pallister, 1935; Peraita, 1946), pantothenic acid (Gopalan, 1946), and nicotinic acid (Cruickshank, 1946). With the general improvement in nutrition after the second world war the syndrome became a rarity. It has become increasingly known, however, that malabsorption from various diseases of the gastrointestinal tract may be associated with neurological abnormalities. Cooke and Smith (1966) reviewed previous reports of neurological disorders associated with sprue and described another 16 cases of adult coeliac neuropathy. Fung and Khoo (1969) reported peripheral neuropathy in about $40 \%$ of cases of tropical sprue. In none of these was the burning-feet syndrome the predominant neurological complication. The following case of burning-feet syndrome in a woman with malabsorption responded dramatically to parenteral riboflavine therapy.

\section{Case Report}

A 21-year-old Indian housewife complained of pain in the soles of her feet of two weeks' duration. This was gradual in onset but was progressively getting worse. The pain was severe and burning "like fire", being persistent throughout the day and night but much worse during the night. She was unable to stand or walk, and suffered from insomnia. She had consulted a doctor at a maternity clinic and was told that she was "short of vitamins"; however, two oral multivitamin tablets three times daily given for two weeks did

\footnotetext{
* Senior Registrar in Medicine, Medical Unit 1, Outram Road General Hospital, Singapore 3.

† Professor of Medicine, Department of Medicine, University of Singapore, Singapore 3.
}

not relieve her burning pain. Each of these tablets contained thiamine $3 \mathrm{mg}$., riboflavine $1.5 \mathrm{mg}$., pyridoxine $0.5 \mathrm{mg}$., nicotinamide $10 \mathrm{mg}$., and vitamin D 250 i.u.

Three months previously, during the last two weeks of her fifth pregnancy, she had pain in the soles. This pain was less severe and not burning. It subsided spontaneously after parturition. Her earlier pregnancies had not been associated with such pain in the feet.

Her appetite was good. She had not been vomiting and did not have diarrhoea. She never complained of soreness in the tongue. Dietary inquiry showed that, because of personal idiosyncrasies, she was not getting a fair share of a rather defective family diet. The daily family intake of riboflavine was only about half the recommended allowance.

She was distraught with pain. Neither glossitis nor angular stomatitis was present, and no impairment had occurred in her hearing. Her blood pressure was 120/70. Her feet appeared normal and there was no change in their temperature. The dorsalis pedis pulses were easily felt. Muscle power and co-ordination were normal but she was apprehensive about bearing weight on her feet. The soles, however, were not tender to pressure, and appreciation of all sensory modalities was normal. The knee jerks were brisk but the ankle jerks were normal. Both plantar responses were flexor.

The results of relevant laboratory investigations were a haemoglobin level of $10.3 \mathrm{~g} . / 100 \mathrm{ml}$; serum iron was $84 \mu \mathrm{g} . / 100 \mathrm{ml}$., serum vitamin $B_{12} 515 \mu \mathrm{g} . / \mathrm{ml}$, , and serum folic acid $1.4 \mathrm{ng} . / \mathrm{ml}$ The serum albumin was $3.4 \mathrm{~g} . / 100 \mathrm{ml}$. and globulin $3.6 \mathrm{~g} . / 100 \mathrm{ml}$; serum calcium $8.8 \mathrm{mg} . / 100 \mathrm{ml}$. and serum pyruvate $0.3 \mathrm{mg} . / 100 \mathrm{ml}$ The sternal marrow showed increased cellularity, with moderate normoblastic hyperplasia; no megaloblasts were seen. The xylose excretion test with a $25-\mathrm{g}$. xylose load revealed a five-hour urinary excretion of only $0.7 \mathrm{~g}$. of xylose; a flat curve was obtained from the glucose tolerance test. Five hours after an oral dose of 350,000 i.u. of vitamin $A$ the rise in her serum vitamin $A$ level was only 340 i.u. $/ 100 \mathrm{ml}$. serum, the normal being at least 500 i.u./ $100 \mathrm{ml}$. Jejunal biopsy showed partial villus atrophy. The jejunum and ileum, however, appeared normal in barium small-bowel studies.

The diagnosis was burning-feet syndrome with malabsorption. She was given an ordinary hospital diet but liver was excluded. Analgesics did not relieve her pain, while spraying her soles with ethylchloride was equally ineffective. She was then given intramuscular injections of riboflavine $6 \mathrm{mg}$. daily. Within three days the burning pain had subsided to such an extent that she was anxious to be discharged from hospital, and by the sixth day of parenteral riboflavine therapy she was completely free from pain and walking about normally. Oral folic acid $5 \mathrm{mg}$. three times daily was subsequently given in addition.

\section{Discussion}

The burning-feet syndrome is rare in Singapore. It is curious that among the prisoners-of-war who had it nobody ever found out why it affected some and spared others. It seemed to pick out random cases as if there might be a partial inborn deficiency, perhaps in absorption, of the susceptible persons. 